\title{
Erratum to: Measuring Technical Efficiency in Primary Health Care: The Effect of Exogenous Variables on Results
}

José Manuel Cordero-Ferrera • Eva Crespo-Cebada •

Luis R. Murillo-Zamorano

Published online: 13 October 2011

(C) Springer Science+Business Media, LLC 2011

Erratum to: Journal of Medical Systems

DOI 10.1007/s10916-009-9390-6

The article by Cordero-Ferrera et. al., entitled "Measuring Technical Efficiency in Primary Health Care: The Effect of Exogenous Variables on Results" was published in Volume 35, Issue 4 (2011) 35:545-554. It should have been published as part of the Special issue on Performance Measurement in Health Sector, to appear in Volume 35, Issue 5 (2011).

The online version of the original article can be found at http://dx.doi. org/10.1007/s10916-009-9390-6.

J. M. Cordero-Ferrera $(\bowtie) \cdot$ E. Crespo-Cebada

L. R. Murillo-Zamorano

University of Extremadura,

Badajoz, Spain

e-mail: jmcordero@unex.es 